Int. J. Morphol.,

26(4):1013-1022, 2008.

\title{
Effects of Oral Nicotine on Rat Liver Stereology
}

\author{
Efectos de la Nicotina Oral en la Estereología del Hígado de Rata
}

"Samuel Santos Valenca; *'Lucas Gouveia; "Wagner Alves Pimenta \& "Luís Cristóvão Porto

VALENCA, S. S.; GOUVEIA, L.; PIMENTA, W. A. \& PORTO, L. C. Effects of oral nicotine on rat liver stereology. Int. J. Morphol., 26(3):1013-1022, 2008.

SUMMARY: Nicotine is the more abundant component in cigarette smoke. Because nicotine is first metabolized in the liver, our aim was to investigate the effects of nicotine on this organ by biochemical and stereological methods. Male Wistar rats were treated with oral nicotine $(\mathrm{ON})$ diluted in drinking water during 32 days. The control group was treated with drinking water in the same period. Rats were sacrificed 24 hours after last day, the blood was collected and the liver was removed. Lipidogram was performed by enzymatic method and collagen fibers, fat globules and hepatocytes were count in the liver by stereological methods. We observed in control group preserved hepatocytes, with no presence of inflammatory cells. However in the ON group was possible to observe varied size of hepatocytes with cloudy cellular limits and histoarchitecture loss. Capillaries were fully of red blood cells. We observed also an increase of fat globules with small size. We observed in leucogram a reduction of leukocytes number (lymphocytes, neutrophils and monocytes) in the ON group in comparison to control group. The lipidogram showed an increase of triglycerides and total cholesterol for ON group when compared to control group. Moreover, a reduction of HDL- cholesterol was observed in ON group when compared to control group. Numerical density of hepatocytes was lesser in ON group when compared to control group. We suggest harmful effects of oral nicotine in liver induced by toxic mechanism with reduction of hepatocytes number and disturbance in lipid metabolism.

KEY WORDS: Nicotine; Rat; Liver; Stereology.

\section{INTRODUCTION}

Cigarette smoke has enormous negative health consequences worldwide, and the use of tobacco is still rising globally (CDC, 2000). Although approximately 4000 components occur in the cigarette, nicotine is the alkaloid most active in the tobacco. Nicotine is not a direct cause of most tobacco-related diseases, but it is highly addictive (Djordjevic et al., 1989; Benowitz, 1992; Shihadeh \& Saleh, 2005). The addictiveness of nicotine is the cause of the continuing use of tobacco products, which in turn results in exposure to the diverse array of carcinogens and other bioactive compounds in tobacco (Brown et al., 2001; Campain, 2004). Nicotine is an amine composed of pyridine and pyrrolidine rings (Trushin \& Hecht, 1999). It has been shown that nicotine can cross the biological membranes including the blood brain barrier (Balfour et al., 2000). The actions of nicotine have been extensively investigated in human, in animal, and in a variety of cell systems (Gryglewski, 1968; Ashakumary \& Vijayammal, 1997; Benowitz \& Gourlay, 1997; Benowitz et al., 2002; Pausova et al., 2003; Cooke \& Bitterman, 2004; Valenca et al., 2004). The predominant effects of nicotine in the whole intact ani- mal or human consist of an increase in pulse rate, blood pressure, increase in plasma free fatty acids and lung injury (Kavitharaj \& Vijayammal, 1999; Liu et al., 2001; Benowitz et al., 2002; Pausova et al.; Valenca et al.). In addition, nicotine has also been found to disturb the antioxidant defense mechanisms in rats fed a high fat diet (Senthilkumar et al., 2004; Kalpana et al., 2005; Perlemuter et al., 2005). Nicotinic receptor stimulation has also been shown to induce the transcription factors c-fos and c-jun and to stabilize the intracellular levels of transforming growth factors (Pennypacker et al., 1992; Rakowicz-Szulczynska et al., 1994; Cucina et al., 1999; Pandey et al., 1999; Cucina et al., 2000; Fang \& Svoboda, 2005; Lane et al., 2005). However nicotine medications are widely used as nicotine replacement therapies to assist smoking cessation and more recently have been proposed for use concurrently with smoking as part of a risk reduction strategy (Fant et al., 1999; Balfour et al.). Nicotine has also been studied as an experimental therapy for Parkinson's disease, Alzheimer's disease, and ulcerative colitis (Westman et al., 1995; Baron, 1996; Birtwistle \& Hall, 1996).

\footnotetext{
* Tissue and Repair Laboratory, Histology and Embryology Department - State University of Rio de Janeiro, Rio de Janeiro, RJ - Brazil.

** Adventist Faculty of Bahia, Cachoeira, BA - Brazil.
} 
Nicotine is metabolized by various pathways, of which cotinine is the primary product of the $\mathrm{C}$-oxidation pathway of nicotine biotransformation (Nakajima et al., 1996; Wang et al., 2005). While the liver is considered to be the major site of nicotine biotransformation, metabolism also occurs in the lung and kidney (Nakajima et al.; Trushin \& Hecht). Nicotine is metabolized by CYP forms to a nicotine10(50)-minimum ion which is converted to cotinine by a cytosolic aldehyde oxidase enzyme (Price et al., 2004; Ochiai et al., 2006). In rat liver nicotine is metabolized by CYP1A2, CYP2B1, CYP2C11 and other CYP forms; CYP2B1 also being constitutively expressed in rat lung (Ochiai et al.).

Fatty liver or steatosis refers to a histopathological condition characterized by an excessive accumulation of lipids, primarily triglycerides, within hepatocytes (Perlemuter et al.; Wang et al., 2006). Fatty liver can be classified as macrovesicular or micro-vesicular steatosis, depending on the size of the lipid vacuoles (Caraceni et al., 2005). Besides chronic ingestion of alcohol, macro-vesicular fatty liver is also seen in other conditions, including Type 2 diabetes, obesity, metabolic syndrome and cigarette consumption (Benowitz; Ashakumary \& Vijayammal; Benowitz et al., 2002; Wang et al., 2006). To develop fatty liver, it has been recently suggested that one prerequisite condition should exist, i.e., a source of oxidative stress capable of initiating significant lipid peroxidation. Both animal data and human studies have shown a link between fatty liver and oxidative stress and lipid peroxidation (Grattagliano et al., 2003; Nakamoto et al., 2003; Senthilkumar et al.; Perlemuter et al.). Mitochondria are thought to be the source of the reactive oxygen species (ROS) leading to lipid peroxidation and some evidences shown nicotine-induced oxidative damage (Perlemuter et al.; Wang et al., 2006).

Despite some good effects for some systems and the help in quit smoking, nicotine is a drug and its mechanisms of action on body are not completely understood. Because nicotine is mainly metabolized in the liver, the aim of the present work is to analyze the sequence of events, relative to hepatic discords by biochemical and stereological tools.

\section{MATERIAL AND METHOD}

Animals. Male Wistar rats (10 weeks of age, $280 \pm 20 \mathrm{~g}$ ) were divided in two groups: control ad nicotine treated. Animals were housed in individual cages, and maintained on a 12-h light/12-h dark cycle with ambient temperature of $20-22^{\circ} \mathrm{C}$, and had free access to conventional laboratory chow. Nicotine was administered in drinking water. The Biology Institute Roberto Alcantara Gomes Animal Research Ethics Committee - UERJ, approved this study.
Nicotine administration. Prior to the experimental procedure, individual water intake was estimated. Nicotine was administered in the drinking water to rats $(n=6)$ for 32 days. Nicotine solution $5 \mathrm{mg}$ in $10 \mathrm{ml}$ per day for each animal was prepared using filtered water and nicotine ((-)nicotine ([-]-1methyl-2-[3-pyridyl]-pyrrolidine, Sigma, St. Louis, USA). Nicotine solution was prepared daily. Special drinking bottles were used to avoid nicotine solution exposition to light. Similar oral nicotine administration resulted in 33,67 $\pm 10,49 \mathrm{ng} / \mathrm{ml}$ of blood nicotine (Liu et al., 2003). The control group (6 rats) received filtered water 10 $\mathrm{ml} /$ day during entire treatment. Body weights were recorded once a week and all handlings were carried out between 9 and 10 a.m. to minimize effects of circadian rhythm.

Blood leukocytes and plasma lipids analysis. All blood tests were determined in the Labs - Clinical Pathology Laboratory (Rio de Janeiro, Brazil) which subscribes to the National External Quality Assurance Scheme and is accredited by Brazilian Clinical Pathology Society program for quality (PELM). At the end of the experiment, the animals were water-deprived overnight before blood collection, deeply anesthetized, and blood samples were taken from the right ventricle of the heart; they were then killed by exsanguinations. Plasma was prepared and used for laboratory tests. The plasma was separated from the blood by centrifugation at room temperature for $15 \mathrm{~min}$ at $120 \mathrm{~g}$ and stored at $-80^{\circ} \mathrm{C}$ until the lipids were analyzed. Lymphocyte $\left(\mathrm{x} 10^{6}\right)$, monocyte $\left(\mathrm{x} 10^{6}\right)$ and neutrophil $\left(\mathrm{x} 10^{6}\right)$ counting were obtained with an automated Laser Flowcytometer hematology system (Coulter Diagnostics). Plasma total cholesterol, determined by cholesterol oxidase/ peroxidase assay, HDL cholesterol and triglycerides were measured with enzymatic assays (Advia 120, Bayer Diagnostics).

Liver histology and stereology. The liver was removed, the liver mass (LM) and liver volume (LV) were measured by the liquid displacement method of Scherle (Scherle, 1970), the organ was separated into several minor fragments kept for $48 \mathrm{~h}$ at room temperature in a fixative (freshly prepared $4 \% \mathrm{w} / \mathrm{v}$ formaldehyde in $0.1 \mathrm{M}$ phosphate buffer, $\mathrm{pH} 7.2$ ), embedded in Paraffin (Sigma Co., St. Louis, MO, USA), sectioned at $3 \mu \mathrm{m}$ thickness, and the sections were stained with hematoxylin-eosin and Sirius Red. The liver was analyzed in light microscopy, considering the hepatocytes and the fat globules, as well as the sinusoids. Several hepatic fragments per animal (up to 10 fragments) were embedded together and faced to be cut randomized. Several slices were cut (up to 10 slices) from each animal and .six microscopic fields were randomly analyzed blindly moving the stage of the microscope. The analysis used a video-microscopic 
system (Zeiss-axioplan microscope with planachromatic objectives and the cycloid test system (composed of 16 short lines, d, and 16 test points, PT; the test-line length, LT, is 16d). The stereological parameters were analyzed considering only the well-preserved structures and not crossing the forbidden line:

* Volume density (collagen fibers, fat globules and hepatocytes) $\mathrm{Vv}=\mathrm{PP} / \mathrm{PT}(\%)$ (PP represents the points hitting the structure);

* Numerical density (hepatocyte nuclei) where Q-A is the number of hepatocyte nuclei seen in focus only in the look-up plane when they were partly or totally inside the frame and did not intersect the left or inferior exclusion edges or their extension, $t$ was the thickness of the dissector, and AT was the test area $\left(1800 \mu \mathrm{m}^{2}\right)$ (Fig. 1).

$$
N_{V}[h]=\frac{Q_{A}^{-}}{t A_{\mathrm{T}}} / \mathrm{mm}^{3}
$$

The Nv[h] used the 'optical dissector' method defined with two parallel sections $3 \mu \mathrm{m}$ distant (manually controlled). Six random dissector pairs were analyzed for each specimen. The collagen fibers, fat globule and hepatocytes absolute and relative volume $(\mathrm{V}$ and $\mathrm{Vv}$ to [cf], [fg], and [h], respectively) as well as the absolute number of hepatocytes $(\mathrm{N}[\mathrm{h}])$ were determined as the product of the volume densities of these structures and the numerical density of the hepatocytes by the hepatic volume previously measured (Aguila et al., 2003; Marcos et al., 2006).

Statistical analysis. For comparison between control and nicotine-treated group, Student's ttest Welch corrected using a $\mathrm{p}<0.05$ was performed to determine differences among plasma lipids analysis and leukocytes in blood. For comparison among stereological results MannWhitney t-test using a $\mathrm{p}<0.05$ was performed. InStat Graphpad software was used to perform statistical analysis (GraphPad InStat version 3.00 for Windows 95, GraphPad Software, San Diego California, USA).

\section{RESULTS}

In the control group (CG) was possible to observe the preserved hepatocytes and normal capillaries form without inflammatory cells (Fig. 1a). A small number of fat globules were detected (not evidenced through the photomicrographs due small size). However in the oral nicotine group $(\mathrm{ON})$ it was possible to observe varied sizes of hepatocytes with uncertain cellular limits and histoarchitecture loss (Fig. 1b). The capillaries were full of red blood cells. It was possible to observe an increase in the number of fat globules of small size.
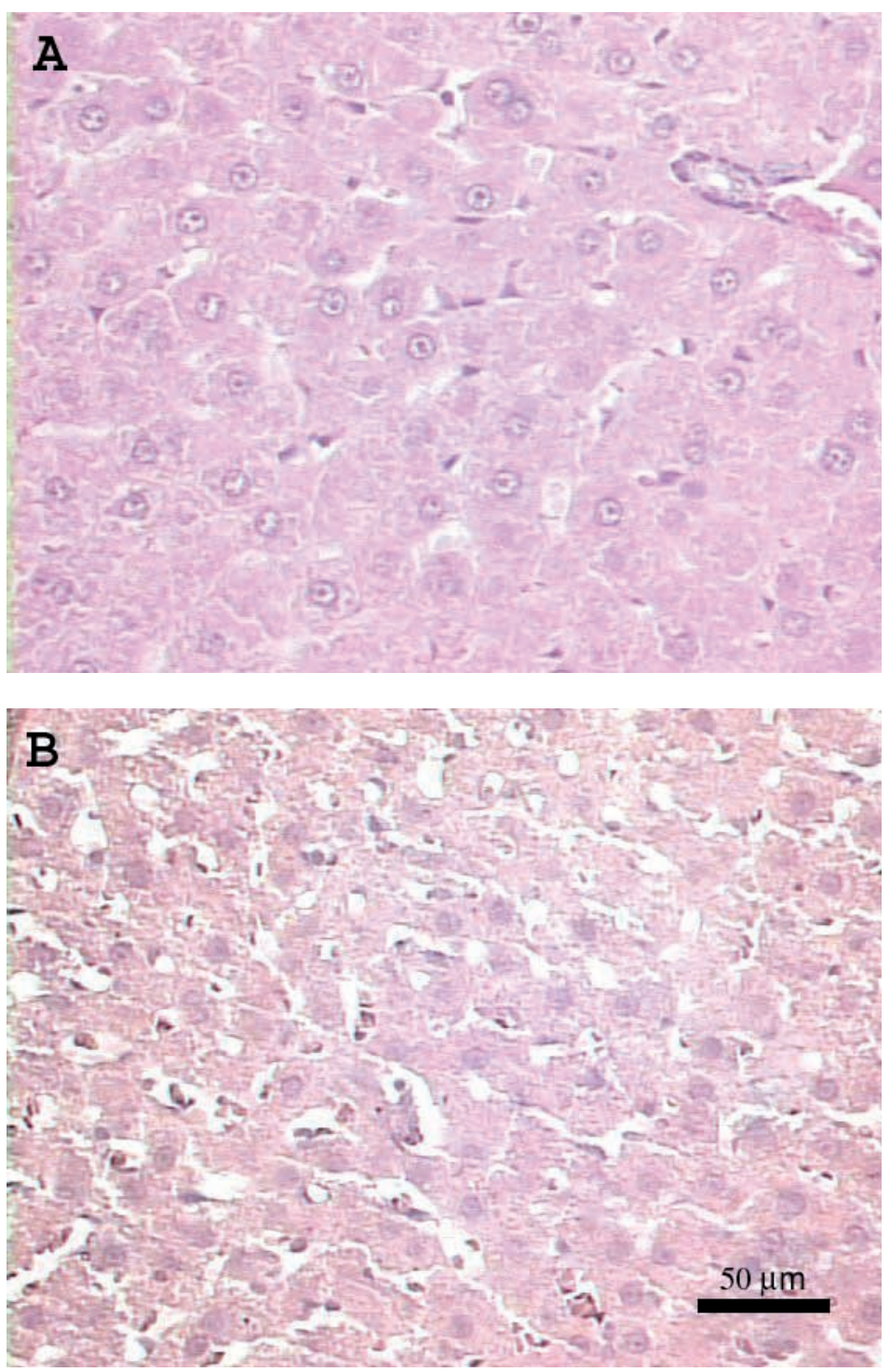

Figs. 1a and 1b: Photomicrographs of the liver with the same magnification and staining (Hematoxylin-eosin) in the control and oral nicotine. The control group showed preserved hepatocytes and normal capillaries form without inflammatory cells. A small number of fat globules were detected (not evidenced through the photomicrographs due small size). The Oral nicotine group showed varied sizes of hepatocytes and diffuse microvesicular steatosis. The capillaries were full of red blood cells. 
The stain for collagen fibers did not show changes between the CG and ON, observed mainly at disse space, portal vein and hepatic lobes.

We observe a reduction of leukocytes $(\mathrm{x} 106 / \mathrm{ml})$ between the $\mathrm{CG}$ and $\mathrm{ON}$ (Fig. 4). In the CG was counted $6.5 \pm 0.4$ lymphocytes, $2.6 \pm 0.3$ neutrophils and $0.6 \pm 0.05$ monocytes while in the ON was counted 4.2 \pm 0.2 lymphocytes $(\mathrm{p}<0.01), 1.1 \pm 0.1$ neutrophils $(\mathrm{p}<0.01)$ and $0.2 \pm 0.02$ monocytes $(\mathrm{p}<0.05)$. In the lipidogram triglycerides, total cholesterol and HDL cholesterol were analyzed (Fig. 5). We observe an increase of the triglycerides and total cholesterol $(\mathrm{mg} / \mathrm{L})$ in the $\mathrm{CG}$ of $4.16 \pm 0.6$ and $4.4 \pm 0.09$ in comparison with the $\mathrm{ON}$ for $7.5 \pm 0.6$ and $5.4 \pm 0.2(\mathrm{p}<0.01$ for both) while HDL cholesterol was diminished in the ON $(2.4 \pm 0.1)$ in comparison to the CG $(3.0 \pm 0.02)$ with $\mathrm{p}<0.05$.

Significant changes in the liver volume were not observed if to compare the CG with ON (Table I). The CG presented a liver volume of $12.66 \pm 0.25\left(103 \mathrm{~mm}^{3}\right)$ while the ON presented a liver volume of $12.44 \pm 0.10\left(103 \mathrm{~mm}^{3}\right.$ ). The $\mathrm{Vv}$ of collagen fibers ( $\mathrm{Vv}[\mathrm{cf}])$ in the $\mathrm{CG}$ was $3.8 \pm 0.69 \%$ while in the ON was $4.76 \pm 0.99 \%$ (Fig. 2). The $\mathrm{V}$ of collagen fibers $(\mathrm{V}[\mathrm{cf}])$ presented resulted similar to the $\mathrm{Vv}(\mathrm{cf})$ with $550 \pm 67.7 \mathrm{~mm}^{3}(\mathrm{CG})$ and $682 \pm 86.4 \mathrm{~mm}^{3}$ (ON) (Fig. 3). The increase in the collagen fibers was not significant for both stereological parameters $\mathrm{Vv}$ and $\mathrm{V}$. But the $\mathrm{Vv}$ of fat globules $(\mathrm{Vv}[\mathrm{fg}])$ presented a significant

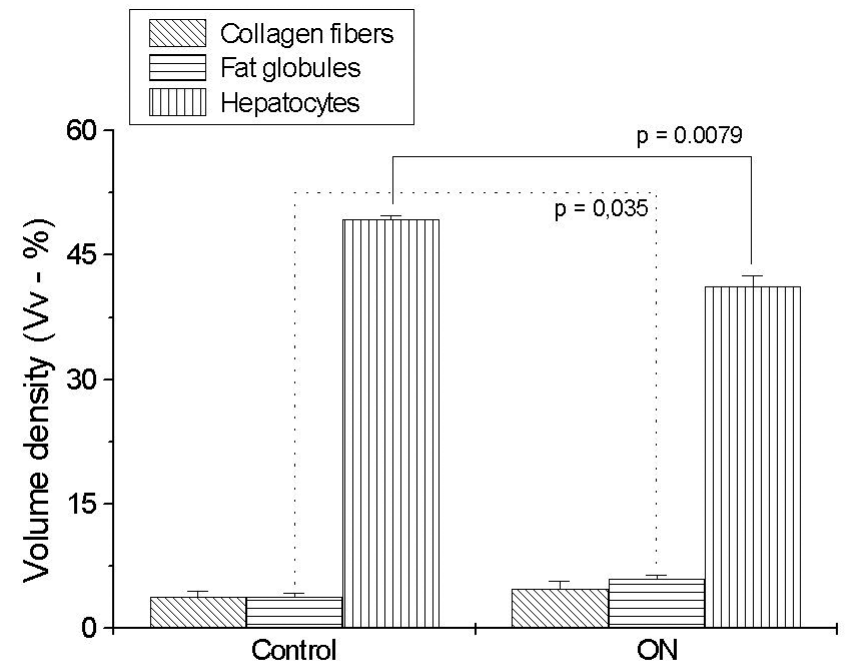

Fig. 2. Volume density of Collagen fibers ( $\mathrm{Vv}[\mathrm{cf}])$, fat globules $(\mathrm{Vv}[\mathrm{fg}])$ and hepatocytes $(\mathrm{Vv}[\mathrm{h}])$ in the control and oral nicotine $(\mathrm{ON})$ groups. There is no difference between control and oral nicotine groups for $\mathrm{Vv}(\mathrm{cf})$. However, the $\mathrm{Vv}(\mathrm{fg})$ was increased in ON when compared to control group. In contrast the $\mathrm{Vv}(\mathrm{h})$ was decreased in $\mathrm{ON}$ when compared to control group. increase in the $\mathrm{ON}(5.95 \pm 0.53 \%)$ in comparison to the $\mathrm{CG}$ $(3.8 \pm 0.44 \%)$ with $\mathrm{p}=0.035$. Similar result was observed in the $\mathrm{V}$ of fat globules (V[fg]) with $\mathrm{p}=0,0009$ (Fig. 3). However a significant decreased of the $\mathrm{Vv}(\mathrm{h})$ and $\mathrm{V}(\mathrm{h})$ were observed with $\mathrm{p}=0,0079$ and 0,0012 respectively (Figs. 2 and 3) in the ON compared to CG. For the Nv(h) we observed a significant reduction $(\mathrm{p}=0,016)$ of $42.2 \pm 0.98103 / \mathrm{mm}^{3}$ (CG) for $36.8 \pm 1.19103 / \mathrm{mm}^{3}(\mathrm{ON})$ (Table I).

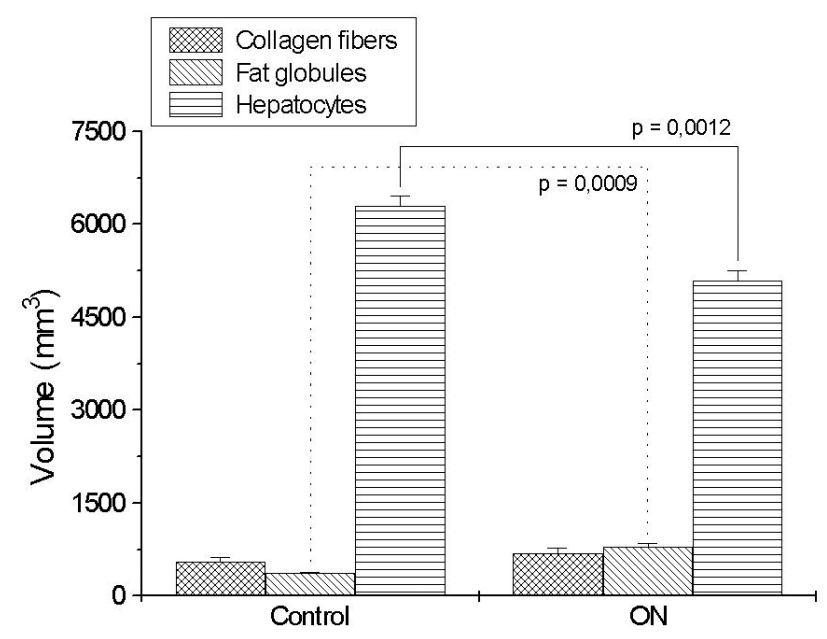

Fig. 3. Total volume of Collagen fibers (V[cf]), fat globules (V[fg]) and hepatocytes $(\mathrm{V}[\mathrm{h}])$ in the control and oral nicotine $(\mathrm{ON})$ groups. The results in this figure were similar with the figure 2.

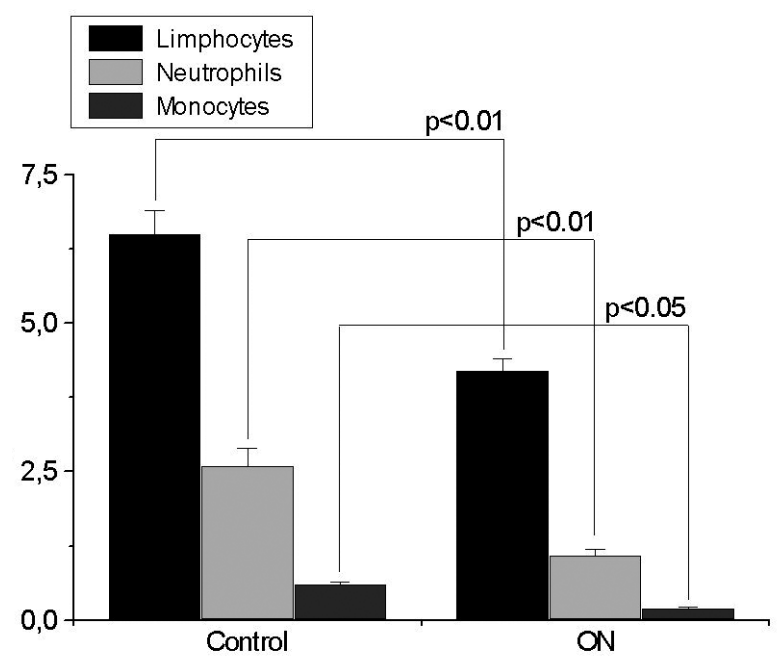

Fig. 4. Total leucocytes count in control and ON groups. There were a decreased in lymphocytes, neutrophils and monocytes in ON compared to control group. 


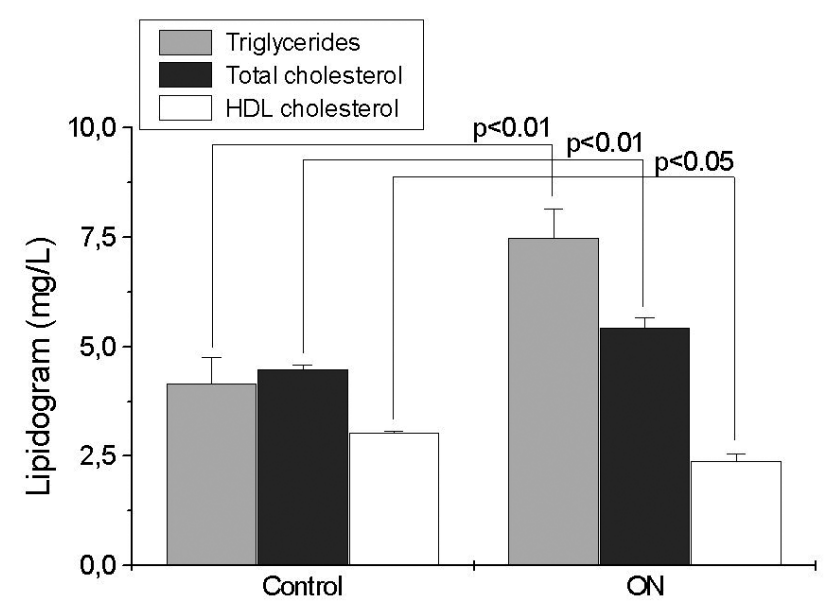

Fig. 5. Lipidogram analysis in control and ON groups. There were a increase in triglycerides and total cholesterol in $\mathrm{ON}$ when compared to control group. The HDL was decreased in ON when compared to control group.

Table I. Quantitative results of liver mass and hepatocytes number (mean $\pm \mathrm{SD})$.

\begin{tabular}{ccc}
\cline { 2 - 3 } & Biometry & Numerical \\
\hline Groups & $10^{3} \mathrm{~mm}^{3}$ & $10^{3} / \mathrm{mm}^{3}$ \\
Control & $12,66 \pm 0,25$ & $42,2 \pm 0,98$ \\
Oral nicotine & $12,44 \pm 0,10$ & $36,8 \pm 1,19^{*}$ \\
\hline
\end{tabular}

$\mathrm{p}=0.016(*)$.

\section{DISCUSSION}

The alkaloid nicotine is currently available in various formulations, such as chewing gum, topical patches, and nasal spray to stop the smoking habit (Fant et al.; Balfour et $a l$.). The actions of the nicotine have been extensively investigated in humans, animals and a variety of cellular systems (West et al., 2003; Bao et al., 2005; Chu et al., 2005; Fang \& Svoboda, 2005; Benowitz et al., 2006; Ochiai et al.; Ueno et al., 2006; Wang et al., 2006). Predominant nicotine effects consist of: increase in heart rate and cardiac contractility (Franco-Cereceda et al., 1991; Benowitz et al., 2002; Pausova et al., 2003), increase in the blood pressure (Pausova et al.; Ochiai et al.), reduction of temperature skin (Plowchalk et al.; Russell et al., 2004) and mobilization of the sugar in the blood (Gilbert et al., 2000). Reports about In vitro results shown: increase in the hormones synthesis and release (Seaman et al., 1977; Damaj, 2001; Wessler et al., 2003), activation of ERK (Chen et al., 1994; Szajerka \& Kwiatkowska, 1997) and transcription nuclear factors (inflammatory factors as NFkB and AP-1) (Pennypacker et al.; Pandey et al.; Ueno et al.), production of shock proteins
(Wang et al., 2006), induction of oxidative stress (Grattagliano et al., 2003; Senthilkumar et al.; Caraceni et al.; Perlemuter et al.), apoptosis and chromosome aberrations (Tithof et al., 2001; Nakamoto et al.; West et al.; Wang et al., 2006). Our results suggest a clear action of nicotine on the liver and blood. This finding was possible due to stereological and biochemical tools. Our results are important due to the great number smoking and passive smoking people. Another population that is clearly in danger way is the addicting treated people with nicotine to quit smoking.

The mechanism of nicotine toxicity on the rat liver in this study was not fully understood, but in literature was the first time that liver was related by direct injury with nicotine. Considerable evidences point with respect to the involvement of oxidative stress (OS) and damage to the DNA as possible causes of injury in the main organs of the body including the lung (Gamieldien \& Maritz, 2004; Valenca et al.; Ochiai et al.), cardiovascular system (Ashakumary \& Vijayammal; Benowitz \& Gourlay; Benowitz et al., 2002; Cooke \& Bitterman), central nervous system (Pandey et al.; Miksys et al., 2000; Tyndale \& Sellers, 2001), liver (Liu et al., 2003; Price et al.; Kalpana et al.; Serobyan et al., 2005), kidney (Iba et al., 1999; Pausova et al.), testis (Brindis et al., 1973; Kavitharaj \& Vijayammal), and esophagus (Gonzalez et al., 2004). In the rat liver nicotine is metabolized by the CYP1A2, CYP2B1, CYP2C11 and other forms CYP; however CYP2B1 constituently is expressed in the rat lung (Miksys et al.; Gamieldien \& Maritz). Oxidative damage induced by oxidative stress is a process associated with pathogenesis of atherosclerosis (Caraceni et al.). Although our rats not to develop this disease, we observed changes in triglycerides, total cholesterol and HDL cholesterol in the ON. Although to the lack of oxidative stress in our study, we suggest that this mechanism may be responsible by changes in lipidogram. This result is better understood with histological findings of increase in fat globules, confirmed by stereological methods. The lipid content of hepatocytes is regulated by the integrated activities of cellular enzymes that catalyze lipid uptake, synthesis, oxidation, and exportation. Whenever the 'input' of fats into these systems (either because of increased fatty acid delivery, hepatic fatty acid uptake, or fatty acid synthesis) exceeds the fatty acid oxidation or exportation capacity (i.e., 'output'), hepatic steatosis occurs (Caraceni et al.; Perlemuter et al.; Wang et al., 2006). Both micro-vesicular and macro-vesicular steatosis has been shown to represent a poor prognosis and have been associated with steatohepatitis, fibrosis, and cirrhosis (Marcos et al.). Macro-vesicular steatosis results from a complex combination of pathogenetic alterations that include increased delivery, inadequate oxidation, and decreased secretion of various forms of lipid in the liver (Causse et al., 1995; Mion et al., 1995). 
Extracellular matrix was evaluated by quantification of collagen fibers. However was not observed alterations in the special distribution of collagens fibers, although of in vitro studies to show that nicotine in low concentrations was capable to influencing the direction and orientation of fibroblasts on reticular surfaces (Chang et al., 2001; Fang \& Svoboda), to diminished cellular proliferation and to inhibit the alkaline production of phosphatase, fibronectin and collagen (Carty et al., 1996). It is possible that viability and activation of fibroblasts are proportional to the dose and the time of exposition to the nicotine.

Histological findings in this study are directly in disagreement with Liu (Liu et al., 2003) where effects of nicotine administration by long-time was examined by serum transaminase and the histology of the liver. The results showed that hepatocytes were not damaged by nicotine either biochemically or histologically. Despite they measured the glycogen content, key regulatory enzyme activities involved in hepatic glycogen metabolism, as well as gluconeogenic activity. Yours results showed that glycogen content per unit weight of liver decreased significantly on oral nicotine administration. Although phosphorylase activity was significantly increased, glycogen synthetase activity was significantly decreased by nicotine administration (West et al.). This discrepancy in histology result could be due rat type (we used Wistar rats) or the kind of nicotine used.

The nicotine is known by affecting the respiratory system (Gamieldien \& Maritz; Price et al.; Valenca et al.), the skin (Plowchalk et al.; Russell et al.), blood vessels (Cooke \& Bitterman; Valenca et al.) and immunological system (Le Cam et al., 1996; Satoskar et al., 2003; Mamata et al., 2005). Moreover, nicotinic acetylcholine receptors had been identified in lymphocytes, neutrophils and monocytes (Jensen et al., 1998). Some reports show effect of nicotine on the immunological system depression and more specifically on migration and apoptosis of leukocytes (Jensen et al.; Nakamoto et al., 2003; West et al., 2003). Our results show that nicotine affects the number of circulating leukocytes. We suggest a migration of inflammatory cells to brain, skin and lung according some reports, but not liver, besides Inflammatory cells was not evidenced by histology in the rat liver in our study. Other crucial result was the liver analyze by biometry, with no difference between CG and ON. Then increase of fat globules in ON was proportional to the decreased of hepatocytes, with no interference of liver mass.

Current knowledge about the pharmacokinetics and metabolism of nicotine and nicotine analogs are under development as potential therapeutic agents. The focus is on studies in humans, but animal data are mentioned when relevant to the interpretation of human data. The various formulations of nicotine replacement therapy, such as nicotine gum, transdermal patch, nasal spray, inhaler, sublingual tablets, and lozenges, are prescripts to patients but trial use is not very well accompanied. However at this time, there is still no definitive evidence that nicotine directly contributes to human injury, despite some results show it. Studies with others animal species are necessary to determine whether nicotine produces harmful effects.

VALENCA, S. S.; GOUVEIA, L.; PIMENTA, W. A. \& PORTO, L. C. Efectos de la nicotina oral en la estereología del hígado de rata. Int. J. Morphol., 26(4):1013-1022, 2008.

RESUMEN: La nicotina es el componente más abundante en el humo del cigarrillo. Primero porque la nicotina es metabolizada en el hígado, nuestro objetivo fue investigar los efectos de la nicotina sobre este órgano por métodos bioquímicos y estereológicos. Hombre rata Wistar fueron tratados con la nicotina oral (NO) diluida en el agua potable durante 32 días. El grupo control fue tratado con agua potable en el mismo período. Las ratas se sacrificaron 24 horas después del último día, se recogió la sangre y el hígado fue retirado. Lipidogram se realizó por el método enzimático y fibras de colágeno, grasa y hepatocitos se cuentan en el hígado mediante métodos estereológicos. Hemos observado en el grupo control hepatocitos conservados, sin presencia de células inflamatorias. Sin embargo en el grupo ON fue posible observar variado tamaño de hepatocitos con nubes y claros límites celulares y histoarchitecture pérdida. Capilares están plenamente de los glóbulos rojos. Se observó también un aumento de grasa con pequeño tamaño. Hemos observado en leucogram una reducción del número de glóbulos blancos (linfocitos, neutrófilos y monocitos) en el grupo ON, en comparación con el grupo control. El lipidogram mostró un aumento de los triglicéridos y de colesterol total ON grupo comparado con el grupo control. Por otra parte, una reducción del HDL-colesterol se observó en el grupo ON, en comparación con el grupo control. Densidad numérica de los hepatocitos fue menor en el grupo ON, en comparación con el grupo control. Sugerimos oral efectos nocivos de la nicotina en el hígado inducido por tóxicos con mecanismo de reducción de número de hepatocitos y alteraciones en el metabolismo lipídico.

PALABRAS CLAVE: Nicotina; Ratas; Hígado; Estereología. 


\section{REFERENCES}

Aguila, M.B.; Pinheiro Ada, R.; Parente, L.B., Mandarimde-Lacerda, C.A. Dietary effect of different high-fat diet on rat liver stereology. Liver Int., 23:363-70, 2003.

Ashakumary, L. \& Vijayammal, P. L. Effect of nicotine on lipoprotein metabolism in rats. Lipids, 32:311-5, 1997.

Balfour, D.; Benowitz, N.; Fagerstrom, K.; Kunze, M. \& Keil, U. Diagnosis and treatment of nicotine dependence with emphasis on nicotine replacement therapy. A status report. Eur. Heart J., 21:438-45, 2000.

Bao, Z.; He, X. Y.; Ding, X.; Prabhu, S. \& Hong, J. Y. Metabolism of nicotine and cotinine by human cytochrome P450 2A13. Drug Metab. Dispos., 33:25861,2005

Baron, J. A. Beneficial effects of nicotine and cigarette smoking: the real, the possible and the spurious. Br. Med. Bull., 52:58-73, 1996.

Benowitz, N. L. Cigarette smoking and nicotine addiction. Med. Clin. North Am., 76:415-37, 1992.

Benowitz, N. L. \& Gourlay, S. G. Cardiovascular toxicity of nicotine: implications for nicotine replacement therapy. J. Am. Coll. Cardiol., 29:1422-31, 1997.

Benowitz, N. L.; Hansson, A. \& Jacob, P., 3rd. Cardiovascular effects of nasal and transdermal nicotine and cigarette smoking. Hypertension, 39:1107-12, 2002.

Benowitz, N. L.; Lessov-Schlaggar, C. N.; Swan, G. E., Jacob, P., 3rd. Female sex and oral contraceptive use accelerate nicotine metabolism. Clin. Pharmacol. Ther., 79:480-8, 2006.

Birtwistle, J. \& Hall, K. Does nicotine have beneficial effects in the treatment of certain diseases? Br. J. Nurs., 5: 195202, 1996.

Brindis, R. G.; Petersen, B. J.; Thompson, J. H. \& Alfin-Slater, R. B. Lack of effect of chronic nicotine administration on fatty acid distribution in the liver, testis, and adipose tissue of male Fischer-344 rats. J. Lipid Res., 14:688-91, 1973.

Brown, B.; Avalos, J.; Lee, C. \& Doolittle, D. The effect of tobacco smoke, nicotine, and cotinine on the mutagenicity of 4-(methylnitrosamino)-1-(3-pyridyl)-1-butanol (NNAL). Mutat. Res., 494:21-9, 2001.
Campain, J. A. Nicotine: potentially a multifunctional carcinogen? Toxicol. Sci., 79:1-3, 2004.

Caraceni, P.; Domenicali, M.; Vendemiale, G.; Grattagliano, I.; Pertosa, A.; Nardo, B.; Morselli-Labate, A. M.; Trevisani, F.; Palasciano, G.; Altomare, E. \& Bernardi, $\mathrm{M}$. The reduced tolerance of rat fatty liver to ischemia reperfusion is associated with mitochondrial oxidative injury. J. Surg. Res., 124:160-8, 2005.

Carty, C. S.; Soloway, P. D.; Kayastha, S.; Bauer, J.; Marsan, B.; Ricotta, J. J. \& Dryjski, M. Nicotine and cotinine stimulate secretion of basic fibroblast growth factor and affect expression of matrix metalloproteinases in cultured human smooth muscle cells. J. Vasc. Surg., 24:927-34; discussion 934-5, 1996.

Causse, X.; Gargot, D. \& Michenet, P. Liver steatosis. I: Macrovesicular steatosis. Gastroenterol. Clin. Biol., 19:58-65, 1995.

CDC (Centers for Disease Control and Prevention). Statespecific prevalence of current cigarette smoking among adults and the proportion of adults who work in a smokefree environment-United States, 1999. MMWR. 2000:49:978-82, 2000.

Chang, Y. C.; Hu, C. C.; Tseng, T. H.; Tai, K. W.; Lii, C. K. \& Chou, M. Y. Synergistic effects of nicotine on arecolineinduced cytotoxicity in human buccal mucosal fibroblasts. J. Oral Pathol. Med., 30:458-64, 2001.

Chen, Y. P.; Johnson, G. K. \& Squier, C. A. Effects of nicotine and tobacco-specific nitrosamines on hamster cheek pouch and gastric mucosa. J. Oral Pathol. Med., 23:251-5, 1994.

Chu, M.; Guo, J. \& Chen, C. Y. Long-term exposure to nicotine, via ras pathway, induces cyclin D1 to stimulate G1 cell cycle transition. J. Biol. Chem., 280:6369-79, 2005.

Cooke, J. P. \& Bitterman, H. Nicotine and angiogenesis: a new paradigm for tobacco-related diseases. Ann. Med., 36:33-40, 2004.

Cucina, A.; Corvino, V.; Sapienza, P.; Borrelli, V.; Lucarelli, M.; Scarpa, S.; Strom, R.; Santoro-D'Angelo, L. \& Cavallaro, A. Nicotine regulates basic fibroblastic growth factor and transforming growth factor beta1 production in endothelial cells. Biochem. Biophys. Res. Commun., 257:306-12, 1999. 
Cucina, A.; Sapienza, P.; Corvino, V.; Borrelli, V.; Mariani, V.; Randone, B.; Santoro D'Angelo, L. \& Cavallaro, A. Nicotine-induced smooth muscle cell proliferation is mediated through bFGF and TGF-beta 1. Surgery, 127:316-22, 2000.

Damaj, M. I. Influence of gender and sex hormones on nicotine acute pharmacological effects in mice. $J$. Pharmacol. Exp. Ther., 296:132-40, 2001.

Djordjevic, M. V.; Brunnemann, K. D., Hoffmann, D. Identification and analysis of a nicotine-derived Nnitrosamino acid and other nitrosamino acids in tobacco. Carcinogenesis, 10:1725-31, 1989.

Fang, Y. \& Svoboda, K. K. Nicotine inhibits myofibroblast differentiation in human gingival fibroblasts. J. Cell Biochem., 95:1108-19, 2005.

Fant, R. V.; Owen, L. L. \& Henningfield, J. E. Nicotine replacement therapy. Prim. Care., 26:633-52, 1999.

Franco-Cereceda, A.; Lou, Y. P. \& Lundberg, J. M. Ruthenium-red inhibits CGRP release by capsaicin and resiniferatoxin but not by ouabain, bradykinin or nicotine in guinea-pig heart: correlation with effects on cardiac contractility. Br. J. Pharmacol., 104:30510,1991 .

Gamieldien, K. \& Maritz, G. S. Postnatal expression of cytochrome P450 1A1, 2A3, and 2B1 mRNA in neonatal rat lung: influence of maternal nicotine exposure. Exp. Lung Res., 30:121-33, 2004.

Gilbert, D. G.; Dibb, W. D.; Plath, L. C. \& Hiyane, S. G. Effects of nicotine and caffeine, separately and in combination, on EEG topography, mood, heart rate, cortisol, and vigilance. Psychophysiology, 37:583-95, 2000 .

Gonzalez, A. A.; Farre, R. \& Clave, P. Different responsiveness of excitatory and inhibitory enteric motor neurons in the human esophagus to electrical field stimulation and to nicotine. Am. J. Physiol. Gastrointest. Liver Physiol., 287:299-306, 2004.

Grattagliano, I.; Caraceni, P.; Portincasa, P.; Domenicali, M.; Palmieri, V. O.; Trevisani, F.; Bernardi, M. \& Palasciano, G. Adaptation of subcellular glutathione detoxification system to stress conditions in cholinedeficient diet induced rat fatty liver. Cell Biol. Toxicol., 19:355-66, 2003.
Gryglewski, R. Participation of nicotine in damage caused by addiction to tobacco smoking. Przegl. Lek., 24:514-6, 1968.

Iba, M. M.; Fung, J.; Pak, Y. W.; Thomas, P. E.; Fisher, H.; Sekowski, A.; Halladay, A. K. \& Wagner, G. C. Dosedependent up-regulation of rat pulmonary, renal, and hepatic cytochrome P-450 (CYP) 1A expression by nicotine feeding. Drug Metab. Dispos., 27:977-82, 1999.

Jensen, E. J.; Pedersen, B.; Frederiksen, R. \& Dahl, R. Prospective study on the effect of smoking and nicotine substitution on leucocyte blood counts and relation between blood leucocytes and lung function. Thorax, 53:784-9, 1998.

Kalpana, C.; Rajasekharan, K. N. \& Menon, V. P. Modulatory effects of curcumin and curcumin analog on circulatory lipid profiles during nicotine-induced toxicity in Wistar rats. J. Med. Food, 8:246-50, 2005.

Kavitharaj, N. K. \& Vijayammal, P. L. Nicotine administration induced changes in the gonadal functions in male rats. Pharmacology, 58:2-7, 1999.

Lane, D.; Gray, E. A.; Mathur, R. S. \& Mathur, S. P. Upregulation of vascular endothelial growth factor-C by nicotine in cervical cancer cell lines. Am. J. Reprod. Immunol., 53:153-8, 2005.

Le Cam, L.; Lagier, B.; Bousquet, J. \& Pene, J. Nicotine does not modulate IL-4 and interferon-gamma release from peripheral blood mononuclear cells and $\mathrm{T}$ cell clones activated by phorbol myristate acetate and calcium ionophore. Int. Arch. Allergy Immunol., 111:372-5, 1996.

Liu, R. H.; Kurose, T. \& Matsukura, S. Oral nicotine administration decreases tumor necrosis factor-alpha expression in fat tissues in obese rats. Metabolism, 50:79$85,2001$.

Liu, R. H.; Mizuta, M. \& Matsukura, S. Long-term oral nicotine administration reduces insulin resistance in obese rats. Eur. J. Pharmacol., 458:227-34, 2003.

Mamata, Y.; Hakki, A.; Yamamoto, Y.; Newton, C.; Klein, T. W.; Pross, S. \& Friedman, H. Nicotine modulates cytokine production by Chlamydia pneumoniae infected human peripheral blood cells. Int. Immunopharmacol., 5:749-56, 2005.

Marcos, R.; Monteiro, R. A. \& Rocha, E. Design-based stereological estimation of hepatocyte number, by 
combining the smooth optical fractionator and immunocytochemistry with anti-carcinoembryonic antigen polyclonal antibodies. Liver Int., 26:116-24, 2006.

Miksys, S.; Hoffmann, E. \& Tyndale, R. F. Regional and cellular induction of nicotine-metabolizing CYP2B1 in rat brain by chronic nicotine treatment. Biochem. Pharmacol., 59:1501-11, 2000.

Mion, F.; Rousseau, M.; Brazier, J. L. \& Minaire, Y. Human hepatic macrovesicular steatosis: a noninvasive study of mitochondrial ketoisocaproic acid decarboxylation. Metabolism., 44:699-700, 1995.

Nakajima, M.; Yamamoto, T.; Nunoya, K.; Yokoi, T.; Nagashima, K.; Inoue, K.; Funae, Y.; Shimada, N.; Kamataki, T. \& Kuroiwa, Y. Role of human cytochrome P4502A6 in C-oxidation of nicotine. Drug Metab. Dispos., 24:1212-7, 1996.

Nakamoto, N.; Tada, S.; Kameyama, K.; Kitamura, K.; Kurita, S.; Saito, Y.; Saito, H. \& Ishii, H. A free radical scavenger, edaravone, attenuates steatosis and cell death via reducing inflammatory cytokine production in rat acute liver injury. Free Radic. Res., 37:849-59, 2003.

Ochiai, Y.; Sakurai, E.; Nomura, A.; Itoh, K. \& Tanaka, Y. Metabolism of nicotine in rat lung microvascular endothelial cells. J. Pharm. Pharmacol.,. 58:403-7, 2006.

Pandey, S. C.; Xu, T. \& Zhang, D. Regulation of AP-1 gene transcription factor binding activity in the rat brain during nicotine dependence. Neurosci. Lett., 264:214, 1999.

Pausova, Z.; Paus, T.; Sedova, L. \& Berube, J. Prenatal exposure to nicotine modifies kidney weight and blood pressure in genetically susceptible rats: a case of geneenvironment interaction. Kidney Int., 64:829-35, 2003.

Pennypacker, K. R.; Hong, J. S.; Douglass, J. \& McMillian, M. K. Constitutive expression of AP-1 transcription factors in the rat adrenal. Effects of nicotine. J. Biol. Chem., 267:20148-52, 1992.

Perlemuter, G.; Davit-Spraul, A.; Cosson, C.; Conti, M.; Bigorgne, A.; Paradis, V.; Corre, M. P.; Prat, L.; Kuoch, V.; Basdevant, A.; Pelletier, G.; Oppert, J. M. \& Buffet, C. Increase in liver antioxidant enzyme activities in non-alcoholic fatty liver disease. Liver Int., 25:946-53, 2005.
Plowchalk, D. R.; Andersen, M. E. \& deBethizy, J. D. A physiologically based pharmacokinetic model for nicotine disposition in the Sprague-Dawley rat. Toxicol. Appl. Pharmacol., 116:177-88, 1992.

Price, R. J.; Renwick, A. B.; Walters, D. G.; Young, P. J. \& Lake, B. G. Metabolism of nicotine and induction of CYP1A forms in precision-cut rat liver and lung slices. Toxicol. In Vitro, 18:179-85, 2004.

Rakowicz-Szulczynska, E. M.; McIntosh, D. G. \& Smith, M. Growth factor-mediated mechanisms of nicotinedependent carcinogenesis. Carcinogenesis, 15:183946, 1994.

Russell, T.; Crawford, M. \& Woodby, L. Measurements for active cigarette smoke exposure in prevalence and cessation studies: why simply asking pregnant women isn't enough. Nicotine Tob. Res., 6(2):S141-51, 2004.

Satoskar, S. D.; Keyler, D. E.; LeSage, M. G.; Raphael, D. E.; Ross, C. A. \& Pentel, P. R. Tissue-dependent effects of immunization with a nicotine conjugate vaccine on the distribution of nicotine in rats. Int. Immunopharmacol., 3:957-70, 2003.

Scherle, W. A simple method for volumetry of organs in quantitative stereology. Mikroskopie, 26:57-60, 1970.

Seaman, I.; Fontaine, J.; Famaey, J. P. \& Reuse, J. The inhibitory effects of steroidal sex hormones on the responses of the guinea-pig isolated ileum to nicotine and serotonin. Arch. Int. Pharmacodyn. Ther., 230:3403,1977 .

Senthilkumar, R.; Viswanathan, P. \& Nalini, N. Effect of glycine on oxidative stress in rats with alcohol induced liver injury. Pharmazie, 59:55-60, 2004.

Serobyan, N.; Orlovskaya, I.; Kozlov, V. \& Khaldoyanidi, S. K. Exposure to nicotine during gestation interferes with the colonization of fetal bone marrow by hematopoietic stem/progenitor cells. Stem Cells Dev., 14:81-91, 2005.

Shihadeh, A. \& Saleh, R. Polycyclic aromatic hydrocarbons, carbon monoxide, "tar", and nicotine in the mainstream smoke aerosol of the narghile water pipe. Food Chem. Toxicol., 43:655-61, 2005.

Szajerka, G. \& Kwiatkowska, D. Metabolism of nicotine-mechanism and clinical effects of toxicity. Postepy Hig. Med. Dosw., 51:23-38, 1997. 
Tithof, P. K.; Elgayyar, M.; Schuller, H. M.; Barnhill, M. \& Andrews, R. 4-(methylnitrosamino)-1-(3-pyridyl)-1butanone, a nicotine derivative, induces apoptosis of endothelial cells. Am. J. Physiol. Heart Circ. Physiol., 281:1946-54, 2001.

Trushin, N. \& Hecht, S. S. Stereoselective metabolism of nicotine and tobacco-specific N-nitrosamines to 4hydroxy-4-(3-pyridyl)butanoic acid in rats. Chem. Res. Toxicol., 12:164-71, 1999.

Tyndale, R. F. \& Sellers, E. M. Variable CYP2A6-mediated nicotine metabolism alters smoking behavior and risk. Drug Metab. Dispos., 29:548-52, 2001.

Ueno, H.; Pradhan, S.; Schlessel, D.; Hirasawa, H. \& Sumpio, B.E. Nicotine enhances human vascular endothelial cell expression of ICAM-1 and VCAM-1 via protein kinase C, p38 mitogen-activated protein kinase, NF-kappaB, and AP-1. Cardiovasc. Toxicol., 6:39-50, 2006.

Valenca, S. S.; de Souza da Fonseca, A.; da Hora, K.; Santos, R. \& Porto, L. C. Lung morphometry and MMP-12 expression in rats treated with intraperitoneal nicotine. Exp. Toxicol. Pathol., 55:393-400, 2004.

Wang, S. L.; He, X. Y. \& Hong, J. Y. Human cytochrome p450 2s1: lack of activity in the metabolic activation of several cigarette smoke carcinogens and in the metabolism of nicotine. Drug Metab. Dispos., 33:33640, 2005.

Wang, D.; Wei, Y. \& Pagliassotti, M. J. Saturated fatty acids promote endoplasmic reticulum stress and liver injury in rats with hepatic steatosis. Endocrinology, 147:94351,2006 .

Wessler, I.; Schwarze, S.; Brockerhoff, P.; Bittinger, F.; Kirkpatrick, C. J. \& Kilbinger, H. Effects of sex hormones, forskolin, and nicotine on choline acetyltransferase activity in human isolated placenta. Neurochem. Res., 28:489-92, 2003.

West, K. A.; Brognard, J.; Clark, A. S.; Linnoila, I. R.; Yang, X.; Swain, S. M.; Harris, C.; Belinsky, S. \& Dennis, P. A. Rapid Akt activation by nicotine and a tobacco carcinogen modulates the phenotype of normal human airway epithelial cells. J. Clin. Invest., 111:81-90, 2003.

Westman, E. C.; Levin, E. D. \& Rose, J. E. Nicotine as a therapeutic drug. N. C. Med. J., 56:48-51, 1995.
Correspondence to:

Prof. Dr. Samuel Santos Valenca

Tissue and Repair Laboratory

Histology and Embryology Department

IBRAG - UERJ.

Av. Professor Manoel de Abreu 444, $3^{\circ}$ andar CEP: $20.550-170$

Maracanã, Rio de Janeiro

BRAZIL

Telephone (55 21) 2587-6509

Telefax (55 21) 2587-6511

Email: samuelv@hotmail.com

Received: 13-03-2008

Accepted: 28-09-2008 